\title{
European ornithomimosaurs (Dinosauria, Theropoda): an undetected record
}

\author{
$\begin{array}{llll}\text { R. ALLAIN } & \text { R. VULLO } & \text { J. LE LOEUFF } & \\ & \text { J.-F. TOURNEPICHE } & \end{array}$ \\ 'Muséum National d'Histoire Naturelle, Centre de Recherche sur la Paléobiodiversité et les Paléoenvironnements, CNRS/MNHN/ \\ Paris6-UPMC \\ CP 38, 57 rue Cuvier F-75231 Paris cedex 05, France. E-mail: rallain@mnhn.fr \\ ${ }^{2}$ Rennes 1 , Géosciences, CNRS UMR 6118 \\ Campus de Beaulieu bat. 15, 263 avenue du Général Leclerc, F-35042 Rennes cedex, France. E-mail: romain.vullo@univ- \\ rennes1.fr \\ ${ }^{3}$ Musée des Dinosaures \\ F-11260 Espéraza, France. E-mail: jean.leloeuff@dinosauria.org \\ ${ }^{4}$ Musée d'Angoulême \\ 1 rue Friedland, F-16000 Angoulême, France. E-mail: Jftbill@aol.com.
}

\section{A B S T R A C T}

Early Cretaceous ornithomimosaurian theropod dinosaurs have been reported from various localities in Asia, whereas they remain poorly represented and extremely rare in North America, Africa and Europe. So far, the only known European ornithomimosaur is Pelecanimimus from the Barremian of Spain. The recent discovery in southwestern France of a lignitic bone bed in Angeac, which has yielded several hundred ornithomimosaur bones, sheds new light on the ornithomimosaurian fossil record. Based on this new material, we re-evaluate here the systematic position of various isolated theropod bones from the Wealden of England, including historical taxa of uncertain affinities. Based on a unique combination of derived characters, Thecocoelurus and Valdoraptor are linked to the Angeac taxon but are considered to be nomina dubia. Valdoraptor from the Valanginian of West Sussex appears to be the oldest known ornithomimosaur together with the contemporaneous Nqwebasaurus from South Africa. Ornithomimosaurs were a common component of the Early Cretaceous European dinosaur fauna. Their presence in Spain, France and England further strengthens the palaeobiogeographic affinities of the European fossil biota with that of Asia during this period.

KEYWORDS $\quad$ Dinosauria. Theropoda. Ornithomimosauria. Early Cretaceous. Europe. Palaeogeography.

\section{INTRODUCTION}

Since their discovery in 2008 , the lignitic deposits from the Hauterivian-Barremian locality of AngeacCharente (southwestern France) have yielded a rich and diverse vertebrate assemblage. Besides micro-remains of fishes, several reptilian taxa, including three turtles, one plesiosaur, four crocodilians and six dinosaurs have been identified (Allain et al., 2011; Néraudeau et al., 2012). The excavations conducted during the summers of 2010 to 2012 revealed that this bone bed was abundant in ornithomimosaur remains. In April 2013, more than 850 
well-preserved but disarticulated elements, including cranial material, and representing at least 20 individuals, were unearthed from a surface of about 80 square meters. Other dinosaur bones pertain to a gigantic sauropod or to iguanodont and stegosaur ornithischians, which are clearly distinct from those of small theropods.

Based on their overall morphology and on numerous synapomorphies, including an edentulous and downturned dentary, flexed cervical prezygapophyses, a sigmoid ischial shaft and ventrally flattened pedal unguals (Rauhut, 2003; Senter, 2007; Makovicky et al., 2010), the referral of the theropod bones from the Early Cretaceous of Angeac to ornithomimosaurs is definitive (Allain et al., 2011). Some primitive coelurosaur pelvic features observed in the Angeac theropod, such as the squared postacetabular ala of the ilium, the propubic pubis, and the presence of a distal boot on the ischium exclude them from the maniraptorans. According to this preliminary anatomical study, the ornithomimosaur from Angeac belongs to a new taxon (Allain et al., 2011), the complete, formal description of which is beyond the scope of this paper. Currently, the only unambiguous record of an European ornithomimosaur is Pelecanimimus, from the Barremian locality of Las Hoyas in Spain. This primitive toothed form known by a single, incomplete but articulated specimen (Pérez-Moreno et al., 1994) is preserved on a limestone slab and counter-slab, and has never been described in detail. Thanks to the discovery of the ornithomimosaur-dominated bone-bed from the Early Cretaceous of Angeac-Charente, bones of uncertain or controversial affinity from the Wealden group of the Isle of Wight can confidently be referred to ornithomimosaurs. We draw attention here to the biased fossil record of European ornithomimosaurs. The discovery of ornithomimosaurs from the Early Cretaceous of France and England sheds new light on the palaeobiogeography of this group of herbivorous theropods (Kobayashi et al., 1999; Barrett, 2005; Zanno and Makovicky, 2010).

Institutional Abbreviations: ANG: Angeac-Charente Collection, Musée d'Angoulême, Angoulême, France; NHMUK: Collection of the Natural History Museum, London, UK; MIWG: Museum of Isle of Wight Geology, Sandown, UK; UOP: University of Portsmouth, Portsmouth, UK; ZPAL: Institute of Palaeobiology, Polish Academy of Sciences, Warsaw, Poland.

Anatomical Nomenclature: a.pl: anterior pleurocoel; cn: cnemial crest; fc: fibular crest; lc: lateral condyle; lm: lateral malleolus; mc: medial condyle; mm: medial malleolus; ns: neural spine; pa: parapophysis; pdf: pedicular fossa; pf: pneumatic foramen; poz: postzygapophysis; p.pl: posterior pleurocoel; prsf: prespinal fossa; prz: prezygapophysis; vr: ventrolateral ridges; vs: ventral sulcus.

\section{DESCRIPTION}

\section{Cervical vertebra}

An incomplete cervical vertebra (NHMUK PV R181) was discovered in the Wessex Formation (Early Cretaceous, Barremian) of the Isle of Wight during the late nineteenth century by the Reverend William Fox. It was first described under the name Thecospondylus daviesi (Seeley, 1888; Fig. 1C, D, F). Huene (1923) recognized that the referral of NHMUK PV R181 to Thecospondylus, a taxon based on the uninformative internal natural cast of a sacrum, was dubious and coined the new genus Thecocoelurus for the specimen. Naish and Martill (2002) regarded Thecocoelurus daviesi as a nomen dubium, but referred the vertebra to the Oviraptorosauria based on "a number of features unique to oviraptorosaurian coelurosaurs" including a U-shaped space between the prezygapophyses and an hour-glassshaped centrum with a ventral sulcus and ventrolateral ridges. Kirkland et al. (2004) recognized the relationships between NHMUK PV R181 and the oviraptorosaurtherizinosauroid clade but referred the vertebra to the Therizinosauroidea. Most recently, Naish (2011) noticed that the "unique oviraptorosaurian characters" of NHMUK PV R181 are also present in a possible noasaurid cervical vertebra (MACN-PV 622; Agnolin and Martinelli, 2007) from Argentina and referred the Wealden cervical vertebra to the Abelisauroidea. Several ornithomimosaur cervical vertebrae were found at Angeac, one of which, ANG 10175 (described below), is morphologically identical to NHMUK PV R181.

Cervical vertebra ANG 10-175 is exquisitely preserved and complete except for the incomplete right parapophysis, diapophysis and postzygapophysis. Based on the posterior extension of the postzygapophyses and the position of the parapophyses, the cervical vertebra is from the anterior half of the neck. The centrum is low, narrow and $66 \mathrm{~cm}$ long with slightly concave, subrectangular anterior and posterior articular surfaces. While MACN-PV 622 is slightly opisthocoelous (Agnolin and Martinelli, 2007), ANG 10-175 and NHMUK PV R181 are not. Two oval pneumatic fossae are located on the lateral side of the centrum (Fig. 1A). The anterior fossa contains a pneumatic foramen, but the posterior fossa is very shallow and not pierced by a foramen. The parapophyses are located on the anteroventral corners of the centrum and face lateroventrally. In lateral view, the centrum is concave ventrally. The ventral surface of the centrum is nearly flat except in its most anterior part, where two ventrolateral ridges merge anteriorly with the parapophyses and border a shallow sulcus, as in NHMUK PV R181. The neural arch is characterized by a low and anteroposteriorly elongate neural spine, which is $40 \%$ of the neural arch length. The spine is located over the mid-portion of the centrum. The prespinal 
fossa is deep and narrow, with lateral margins defined by distinct spinoprezygapophyseal laminae. Epipophyses are very weakly developed. The diapophysis is positioned near the anterior end of the neural arch. Four well-developed diapophyseal laminae radiate from it. The postzygapophyses are slightly longer than the prezygapophyses and extend slightly beyond the posterior intervertebral articular surface of the centrum. Prezygapophyseal and postzygapophyseal facets are directed dorsomedially and ventrolaterally respectively, with their major axes oriented anteroposteriorly. In dorsal view, the bases of the prezygapophyses are widely separated by a U-shaped space. Anterior pedicular fossae are shallow but present dorsolateral to the neural canal, as in NHMUK PV R181. In anterior view, just above these fossae and lateral to the prespinal fossa, a pair of foramina connects with neural arch pneumatic cavities. These lateral pneumatic recesses are rare among theropods. They have been reported in NHMUK PV R181 and in modified form in Masiakasaurus knopfleri (Carrano et al., 2002), but are unknown in abelisaurids (O'Connor, 2007) and oviraptorosaurs (Sues, 1997; Agnolin and Martinelli, 2007).

\section{Tibia}

A small and slender right tibia (NHMUK PV R186), also discovered by William Fox, is known from the Wessex Formation on the southwestern coast of the Isle of Wight. It has long held the attention of palaeontologists, and has been in turn referred to the ornithopod dinosaur
Hypsilophodon foxii (Lydekker, 1888), to the small coelurosaurs Calamosaurus foxi and Aristosuchus pusillus (Lydekker, 1891; Galton, 1973), to the Ornithomimidae (Welles and Long, 1974), or considered to be an indeterminate coelurosaur (Norman, 1990; Kirkland et al., 1998; Long and Molnar, 1998). More recently, Naish et al. (2001) incorrectly re-identified NHMUK PV R186 as a "highly unusual" left tibia, confusing the anterior face with the posterior one. Galton and Molnar (2005) noticed the mistake and reasserted the close relationships between NHMUK PV R186 and the tibia of the basal coelurosaur Coelurus. We refer to the Galton and Molnar (2005) study for a complete and detailed description of the tibia and we agree with the conclusion that it belongs to a coelurosaur, on the basis of derived characters such as the lack of a medial buttress to accommodate the ascending process of the astragalus (Norman, 1990; Kirkland et al., 1998; Long and Molnar, 1998; Galton and Molnar, 2005).

Tibiae recovered at Angeac include 49 fragmentary specimens and five complete bones, representing at least 16 individuals. An almost complete right tibia (ANG 10-158) is described here. The measurements of a second smaller right tibia (ANG 10-24) are provided in Table 1, along with those of tibiae from other coelurosaurs. Both Angeac tibiae are substantially longer than NHMUK PV R186, but their relative measurements are nearly identical. The $\mathrm{Pl} / \mathrm{Tl}$ and Dw/T1 ratio in NHMUK PV R186 are approximately the same as those of other ornithomimosaurs, while the same in A) left lateral, B) dorsal, E) anterior and G) ventral views. Cervical vertebra (NHMUK PV R181) of an ornithomimosaur from the Wealden of the Isle of Wight in C) right lateral, D) anterior and F) ventral views (modified from Seeley, 1888). See Anatomical Nomenclature for abbreviations. Scale bars: $2 \mathrm{~cm}$. 
TABLE 1. Measurements ( $\mathrm{mm}$ ) and ratios for tibiae of various coelurosaurs. TI: length; PI: anteroposterior length of the proximal end; Dw: width of the distal end. Values indicated with an "e" are estimated

\begin{tabular}{|c|c|c|c|c|c|}
\hline & $\mathrm{Tl}$ & $\mathrm{Pl}$ & $\mathrm{Dw}$ & $\mathrm{Pl} / \mathrm{Tl}$ & $\mathrm{Dw} / \mathrm{Tl}$ \\
\hline \multicolumn{6}{|l|}{ Isle of Wight } \\
\hline NHMUK PV R186 & 160 & 28.5 & 25.3 & 0.18 & 0.16 \\
\hline \multicolumn{6}{|l|}{ Angeac } \\
\hline ANG 10-24 & 320 & 54 & 45 & 0.17 & 0.14 \\
\hline ANG $10-158$ & 385 & 80 & 60 & 0.21 & 0.16 \\
\hline ANG 11-1000 & 402 & 76 & - & 0.18 & - \\
\hline ANG 11-1357 & 349 & 60 & 48 & 0.17 & 0.14 \\
\hline ANG 12-1893 & 462 & $88 \mathrm{e}$ & 76 & $0.19 \mathrm{e}$ & 0.16 \\
\hline ANG 12-1808 & 279 & 47 & 41 & 0.17 & 0.15 \\
\hline \multicolumn{6}{|l|}{ Kinnareemimus } \\
\hline PW5A-110 & 255 & 47 & 33 & 0.18 & 0.13 \\
\hline PW5A-111 & 252 & 41 & 32 & 0.16 & 0.13 \\
\hline \multicolumn{6}{|l|}{ Archaeornithomimus } \\
\hline AMNH 6565 & 401 & 81.3 & 65 & 0.20 & 0.16 \\
\hline \multicolumn{6}{|l|}{ Gallimimus } \\
\hline Z.pal.No.Mg.D-I/94 & 290 & 56 & 45 & 0.19 & 0.16 \\
\hline Z.pal.No.Mg.D-I/1 & 380 & 70 & 58 & 0.18 & 0.15 \\
\hline GI DPS $100 / 11$ & 710 & 163 & 120 & 0.23 & 0.17 \\
\hline \multicolumn{6}{|l|}{ Deinonychus } \\
\hline AMNH 3015 & 312 & 74 & 63 & 0.24 & 0.20 \\
\hline MCZ 4371 & 368 & 84 & 73 & 0.23 & 0.20 \\
\hline \multicolumn{6}{|l|}{ Gigantoraptor } \\
\hline LH V0011 & $1100 \mathrm{e}$ & $?$ & $245 \mathrm{e}$ & - & $0.22 \mathrm{e}$ \\
\hline \multicolumn{6}{|l|}{ Tyrannosaurus } \\
\hline FMNH PR2081 & 1143 & 410 & 346 & 0.36 & 0.30 \\
\hline \multicolumn{6}{|l|}{ Gorgosaurus } \\
\hline NMC 350 & 842 & 183 & 266 & 0.22 & 0.32 \\
\hline
\end{tabular}

ratios are quite different in dromaeosaurs, tyrannosaurs and oviraptorosaurs (Table 1). A portion of the medial condyle is broken off, and the posterior surface of the distal end is slightly crushed, but the bone is otherwise undistorted and remarkably well preserved (Fig. 2C-E, G, H). The proximal surface is nearly flat to slightly concave, with a medial condyle more elevated than the lateral condyle (Fig. 2D). In proximal view, both condyles have a subrectangular shape, and they are separated by a narrow notch posteriorly that extends onto the posterior surface of the shaft (Fig. 2H, I). The medial condyle extends posteriorly beyond the lateral condyle. The latter is strongly offset from the cnemial crest by the incisura tibialis. The cnemial crest curves laterally to the level of the lateral condyle so that the tibia has a hooked profile in proximal view. The apex of the cnemial crest is not higher than the level of the proximal articular surface, unlike the condition in ceratosaurs, basal tetanurans and tyrannosauroids. The fibular crest is well developed on the proximal third of the lateral surface of the shaft. It has a rugose posterior surface with a nutrient foramen at its base. The fibular crest is clearly separated from the proximal articular surface of the tibia. It extends to $56 \mathrm{~mm}$ from the proximal end and has a length of $65 \mathrm{~mm}$. The shaft of the tibia is straight and long. It is convex posteriorly, nearly flat anteriorly, and deeper anteroposteriorly medially than laterally. The anterior surface preserves a long and flattened facet that marks the contact with the fibular shaft. More distally, the shaft also preserves the faint but clearly visible impression of the ascending process of the astragalus, which is thus not fused with the distal end of the tibia. The dorsal tip of the astragalus was located about $61 \mathrm{~mm}$ from the distal end of the tibia. As in all coelurosaurs, there is no medial buttress to accommodate the ascending process of the astragalus. The astragalar facet is not completely flat but exhibits two longitudinal concavities which are also present in NHMUK PV R186. The distal end of the right tibia is slightly humpy to flat anteriorly and strongly convex posteriorly. In distal view, the concave articular surface is expanded both medially and laterally and has a subtriangular outline (Fig. 2G). In anterior view, the lateral malleolus slightly projects farther distally than the medial malleolus (Fig. 2C). The latter is angular as defined by Galton and Molnar (2005), a condition that is also present in some basal tetanurans and in basal coelurosaurs.

The most noticeable difference between NHMUK PV R186 and the Angeac tibiae involves the shape of the cnemial crest. In the Angeac specimens, the cnemial crest is longer than the condyles, and its anteriormost portion is sharper. In contrast, NHMUK PV R186 does not present the same rounded-off square outline (Fig. 2H, I; Galton and Molnar, 2005, fig. 1.6g). A second difference is seen in the distal end of the lateral malleolus, which projects only slightly in NHMUK PV R186, but more distally in the Angeac material. Such a distal projection seems to be highly variable in the ornithomimosaur from Charente and is not observed in any of the 21 distal ends of tibiae recovered at Angeac. Except for these slight dissimilarities, of which the first is probably magnified by the incomplete preservation of the condyles of both the French and English specimens, the tibiae are nearly identical. We therefore can confidently refer NHMUK PV R186 to the Ornithomimosauria. Galton and Molnar (2005, p15) previously noticed the great similarities between the proximal tibia of NHMUK PV R186 and that of Gallimimus. But, following the character description of Rauhut (2003), they argued that the distal articular surface of the tibia of NHMUK PV R186 was rectangular in shape and more than three times wider transversely than anteroposteriorly, therefore regarding it as being closer to Coelurus. We disagree with these interpretations. According to Rauhut (2003, text-fig. 45c, d), the distal articular surface of the tibia from the Isle of Wight is more triangular than rectangular. Also according to the original figure of Lydekker (1891; Fig. 2F), the distal articular surface of the tibia has the same proportion as ANG 10-158 (Fig. 2G) and its transverse to anteroposterior width ratio is only 2.6. The right tibia (UOP-C002-2004), which is, according to Naish (2011), morphologically 
A

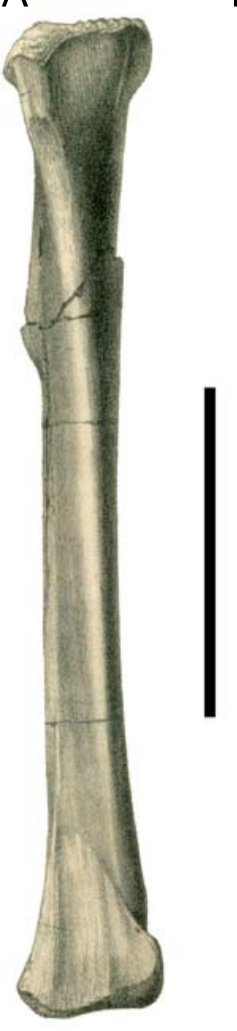

B

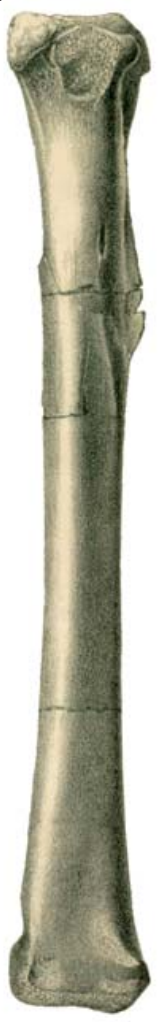

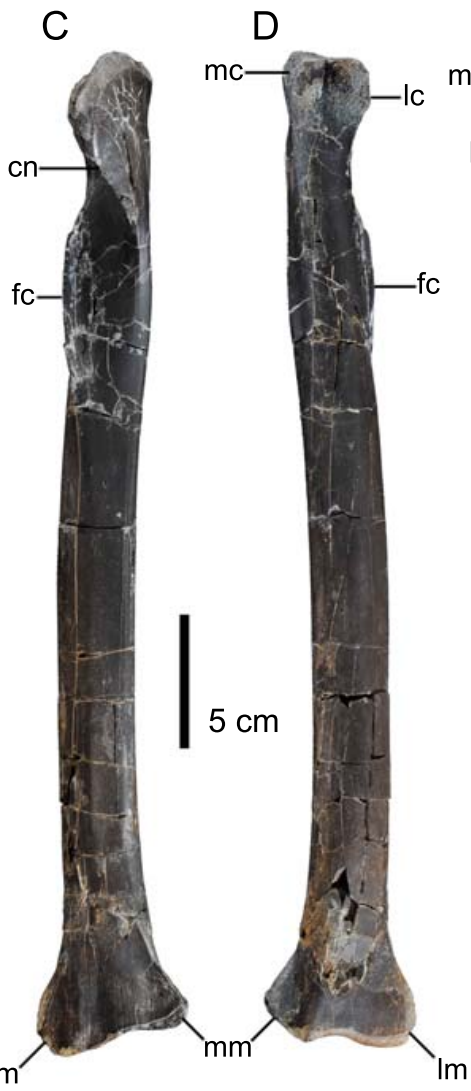
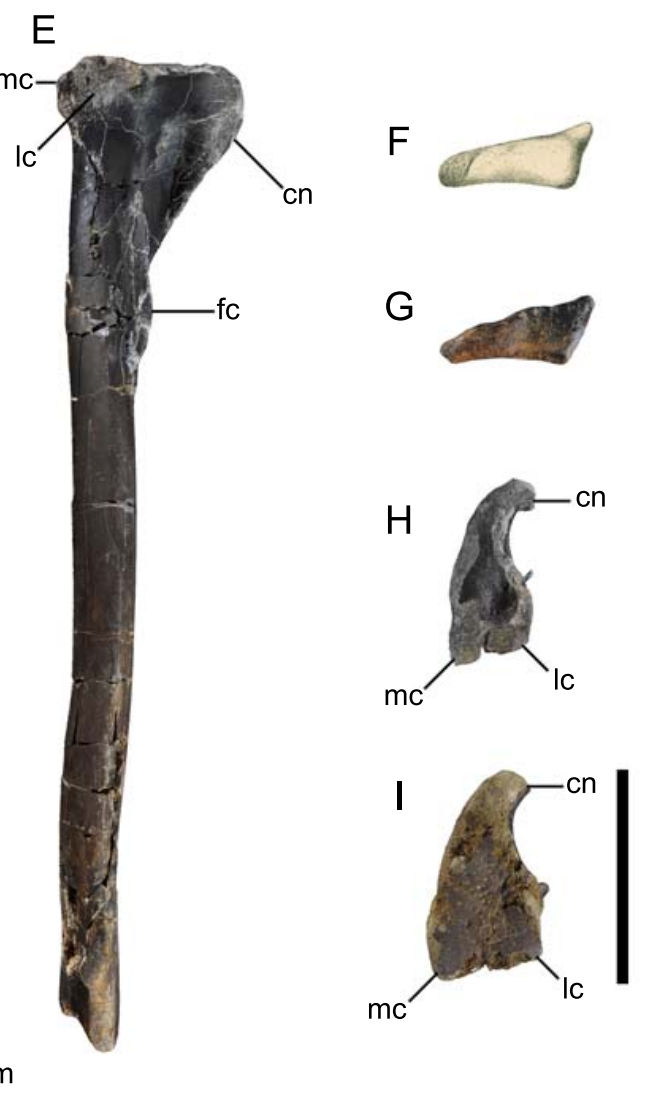

FIGURE 2. Tibiae of European ornithomimosaurs. Right tibia (NHMUK PV R186) of a Wealden ornithomimosaur from the Isle of Wight in A) anterior, B) posterior and F) distal views (modified from Lydekker, 1891). Right tibia (ANG 10-158) of the Early Cretaceous ornithomimosaur from Angeac in C) anterior, D) posterior, E) lateral, G) distal and H) proximal views. I) Right tibia (ANG 10-24) of the Early Cretaceous ornithomimosaur from Angeac in proximal view. See Anatomical Nomenclature for abbreviations. Scale bars: $5 \mathrm{~cm}$.

identical but $34 \%$ larger than NHMUK PV R186, is also regarded as belonging to an ornithomimosaur.

\section{Metatarsals}

Valdoraptor oweni is one of numerous Wealden taxa based on isolated and incomplete material (Fig. 3A), and whose phylogenetic position has long been debated. The material consists of a partial left metatarsus (NHMUK PV R2559) which was originally assumed to belong to the ankylosaur Hylaeosaurus by Owen (1858), then referred to a new species of Megalosaurus, M. oweni by Lydekker (1889), before being designated the holotype of a new allosaurid, Valdoraptor oweni by Olshevsky (1991). Valdoraptor is currently considered to be an indeterminate neotetanuran theropod (Holtz, 2004; Naish and Martill, 2007; Naish, 2011).

Numerous metatarsals have been recovered at Angeac, but all are broken either proximally or distally. Left metatarsals II (ANG 10-240), III (ANG 10-237) and IV (ANG 10-07) do not belong to the same individual but are nonetheless similar in size and have been chosen to illustrate the very close affinities between the metatarsus of the enigmatic Valdoraptor and that of the new ornithomimosaur from Charente (Fig. 3). Naish (2011) listed three characters as diagnostic of Valdoraptor: a mediolaterally compressed metatarsal II, a medially projected distal end of the metatarsal II and the distal extension of the metatarsal III beyond the distal end of the metatarsal II. All these characters have been recognized in the metatarsals of the ornithomimosaur from Angeac. In the latter, the more complete metatarsal IV is compressed mediolaterally as well, as in Nqwebasaurus (De Klerk et al., 2000; Choiniere et al., 2012), and is D-shaped in cross-section. Its distal end projects laterally to metatarsal III (Fig. 3D). As in many theropods, the medial ligament fossa is much deeper than the lateral ligament fossa. Because the metatarsals from Angeac are morphologically almost identical to those of Valdoraptor, and share with them a derived feature unknown in other theropods, the latter taxon is assumed here to be an ornithomimosaur. However, the chronological gap existing between the occurrences of Valdoraptor and the Angeac taxon suggests that the two species are very likely distinct. The mediolaterally compressed metatarsal II might be a potential synapomorphy of some Early Cretaceous ornithomimosaurs The isolated metatarsal II (NHMUK PV R2661) collected by Mantell from Cuckfield 
and referred to Valdoraptor (Naish, 2011) is also regarded as belonging to an ornithomimosaur.

\section{DISCUSSION}

\section{Taxonomic implications}

Based on derived features, both Thecocoelurus and Valdoraptor can be confidently linked to the ornithomimosaur from Angeac and then referred to the Ornithomimosauria. This referral nevertheless raised the problem of the taxonomic status and the possible synonymisation of the French and the two English taxa. If the three taxa could be proved to be synonymous, then Thecocoelurus daviesi (Seeley, 1888) would have the priority over Valdoraptor oweni (Olshevsky, 1991).

Thecocoelurus daviesi has been considered as a nomen dubium by Naish and Martill (2002). The U-shaped space between cervical prezygapophyses and the hourglass-shaped cervical centra with a ventral sulcus and ventrolateral ridges are not diagnostic of this taxon. Indeed, these characters have been observed in the Angeac taxon, and also in Gallimimus bullatus (RA personal observation, ZPAL Mg-DI-94), oviraptorosaurs and abelisauroids (Naish, 2011). The pneumatic recesses located laterally to the prespinal fossa are a synapomorphy shared by Thecocoelurus and the Angeac taxon. However, since pneumatic recesses are also present in modified form in some cervical vertebrae of Masiakasaurus (Carrano et al. 2002), this character must be used with caution. For these
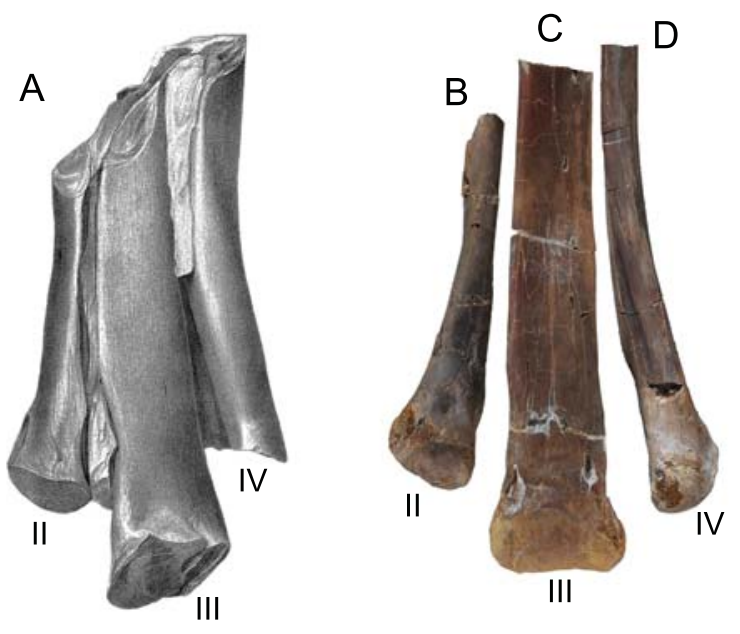

reasons, and given the very limited amount of material (half a vertebra) known for Thecocoelurus, we agree here with the conclusion of Naish and Martill (2002).

As stated above, Valdoraptor oweni has been recently diagnosed by three characters, two of which have a broader distribution among theropods. The medially projected distal end of the metatarsal II, and the distal extension of the metatarsal III beyond the distal end of the metatarsal II are observed not only in numerous ornithomimosaurs including Gallimimus, Kinnareemimus, Struthiomimus, Sinornithomimus and the Angeac ornithomimosaur, but also in other coelurosaurs such as Tyrannosaurus (Brochu 2003). In contrast, the mediolaterally compressed metatarsal II observed in both Valdoraptor and the French ornithomimosaur is unknown in other coelurosaurs. However, this feature is present in at least three noasaurid ceratosaurs: Noasaurus, Masiakasaurus and Velocisaurus (Bonaparte, 1996; Carrano et al., 2002). Therefore, the diagnosis of Valdoraptor oweni is based on homoplastic characters and we consider this taxon to be a nomen dubium.

In conclusion, and pending a complete cladistic analysis including European taxa, we regard here Valdoraptor oweni and Thecocoelurus daviesi as nomina dubia, but we refer their holotypic material to the Ornithomimosauria based on comparisons with the abundant and associated material from the Angeac locality.

Early Cretaceous ornithomimosaurian fossil record and biogeography

The right tibiae NHMUK PV R186 and UOP-C002-2004, the cervical vertebra NHMUK PV R181 which is the holotype of Thecocoelurus daviesi, and the partial left metatarsus, NHMUK PV R2559, representing the holotype of Valdoraptor oweni, as well as the left right metatarsal II NHMUK PV R2661 are significant for being the first ornithomimosaur bones known from England and among the earliest records of this group in the world. According to a preliminary study of the femora from Angeac, the left femur MIWG.6214 (Naish, 2000; 2011) is also tentatively referred here to an ornithomimosaur. All these specimens come from the upper Wessex Formation and are Barremian in age, except Valdoraptor, which was recovered from the Valanginian Grinstead Clay Formation (Naish, 2011). Their presence confirms that ornithomimosaurs were a common component of the Early Cretaceous European dinosaur fauna, as they are now recorded from the Valanginian-Barremian interval in Spain, France and England. Valdoraptor represents one of the oldest known ornithomimosaurs, although the exact age of the Asian forms Kinareemimus from the Early Cretaceous of Thailand (Buffetaut et al., 2009) and the recently described Hexing from the Chinese Liaoning 
Province (Jin et al., 2012) has not been firmly established. Moreover, the small coelurosaur Nqwebasaurus from the Early Cretaceous (mid-upper Valanginian according to Gomez et al., 2002) Kirkwood Formation of South Africa (De Klerk, 2002), which was first thought to belong to the Compsognathidae (Makovicky et al., 2010), has been more recently referred to the Ornithomimosauria (Choiniere et al., 2012). However, the clade surely had a longer history prior to the Early Cretaceous as it is apparent from the Angeac specimen, which already exhibits derived characters such as the loss of teeth in the dentary. The anatomical data of the French ornithomimosaur might be of great value in resolving the phylogenetic relationships of some Late Jurassic coelurosaurs of uncertain affinities, and will be essential for a better understanding of the early evolutionary history of ornithomimosaurs.

So far, most of the Early Cretaceous ornithomimosaurs have been recorded from Asia, where five genera have been described from the Barremian-Albian interval in China (Ji et al., 2003; Makovicky et al., 2010; Jin et al., 2012), Mongolia (Barsbold and Perle, 1984) and Thailand (Buffetaut et al., 2009) (Fig. 4). In addition, the presence of ornithomimosaurs in the eastern part of North America may be attested by the few foot bones coming from the Aptian Arundel Formation in Maryland described as "Ornithomimus affinis" (Gilmore, 1920).

The discovery of the Angeac assemblage, as well as some recent finds in South-East Asia, suggests a complex palaeobiogeographic pattern for the Early Cretaceous and more specifically contacts between Europe and Asia well before the Aptian (which is the time when iguanodonts seem to diversify in Asia: see Russell, 1993; Le Loeuff, 1997). Indeed, there are now many elements in common between European

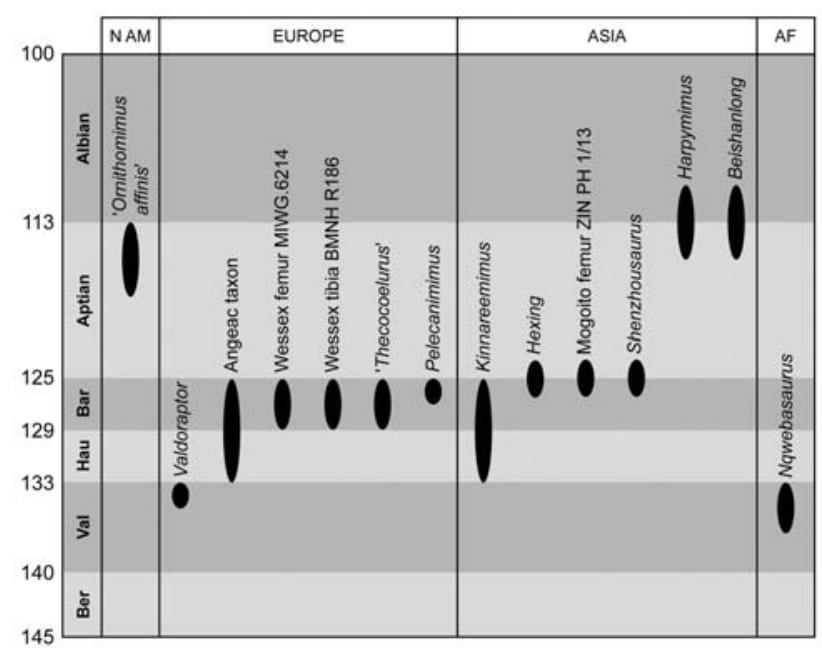

FIGURE 4. Temporal and spatial distribution of Early Cretaceous ornithomimosaurs. Ber: Berriasian; Val: Valanginian; Hau: Hauterivian; Bar: Barremian; N AM: North America; AF: Africa. and Asian assemblages in the mid Early Cretaceous, including several dinosaur groups such as the Baryonychinae (Asia: Buffetaut et al., 2005; Allain et al., 2012; Europe: Charig and Milner, 1997), the Ornithomimosauria (see above), various basal Titanosauriformes and Carcharodontosauria, but also trigonioidoid non-marine bivalves (Sha, 2010; Delvene et al., 2011), goniopholidid and atoposaurid crocodyliforms (Lauprasert et al., 2007, 2011), istiodactylid pterosaurs (Andres and Ji, 2006) and gobiconodontid mammals (CuencaBescós and Canudo, 2003). These rather uniform assemblages may be linked to the very low sea-levels of the earliest Cretaceous which would have allowed faunal exchanges between Euramerica and Asia. The palaeogeographic importance of this distribution, however, is compromised by the absence of well-preserved skeletal remains of "mid" Early Cretaceous (pre-Aptian) age from Africa (Le Loeuff et al., 2012). The close relationships between the Early Cretaceous small South African theropod Nqwebasaurus and other basal Ornithomimosauria (Choiniere et al., 2012) suggest that the latter were biogeographically widespread before Pangaean breakup, as it has been assumed for many coelurosaurian clades (Makovicky et al., 2005). If ornithomimosaurs seem to be quite widespread in the Early Cretaceous, they have a much more restricted distribution in the Late Cretaceous. They are among the most common dinosaurs in the Late Cretaceous of western North America and Asia, but so far no definitive ornithomimosaur remains are known from the Late Cretaceous of Europe (to date, only a humerus fragment and an ungual phalanx have been tentatively ascribed to this group; see Mateus et al., 2010) or Gondwana.

\section{ACKNOWLEDGMENTS}

We are indebted to Jean-Marie, Philippe and Vincent Audoin and the technical help of the Audoin Company for their useful collaboration. We are greatly indebted to Dominique Augier and Renaud Vacant who have prepared much of the material collected and contributed in the field works; to Philippe Loubry and Lilian Cazes for the photographs; to Jeffrey A. Wilson, Darren Naish and José Luis Sanz for providing valuable comments on different versions of the manuscript. Christopher J. Duffin is warmly thanked for improving the English style. We are grateful to Adam Halamsky and Magdalena Borsuk-Bialynicka for access to specimens in their care at the Institute of Palaeobiology of the Polish Academy of Sciences. Finally, we thank all the colleagues, students and amateur palaeontologists who have participated in the excavations during the summers of 2010 to 2012.

\section{REFERENCES}

Agnolin, F.L., Martinelli, A.G., 2007. Did oviraptorosaurs (Dinosauria; Theropoda) inhabit Argentina? Cretaceous Research, 28, 785-790. 
Allain, R., Vullo, R., Leprince, A., Néraudeau., D., Tournepiche, J.-F., 2011. An ornithomimosaur-dominated bone bed from the Early Cretaceous of southern France. 71st Meeting of the Society of Vertebrate Paleontology, Las Vegas, Program and Abstracts. Journal of Vertebrate Paleontology (Supplement online), 61.

Allain, R., Xaisanavong, T., Richir, P., Khentavong, B., 2012. The first definitive Asian spinosaurid (Dinosauria: Theropoda) from the Early Cretaceous of Laos. Naturwissenschaften, 99, 369-377.

Andres, B., Ji, Q., 2006. A new species of Istiodactylus (Pterosauria, Pterodactyloidea) from the Lower Cretaceous of Liaoning, China. Journal of Vertebrate Paleontology, 26, 70-78.

Barrett, P.M., 2005. The diet of ostrich dinosaurs (Theropoda: Ornithomimosauria). Palaeontology, 48, 347-358.

Barsbold, R., Perle, A., 1984. On first new find of a primitive ornithomimosaur from the Cretaceous of the MPR. Paleontologicheskiy Zhurnal, 2, 121-123.

Bonaparte, J.F., 1996. Cretaceous tetrapods of Argentina. Münchner Geowissenschaftliche Abhandlungen, Reihe A 30, 73-130.

Brochu, C. 2003. Osteology of Tyrannosaurus rex: Insights from a nearly complete skeleton and high-resolution computed tomographic analysis of the skull. Society of Vertebrate Paleontology Memoir, 7, 1-138.

Buffetaut, E., Suteethorn, V., Le Loeuff, J., Khansubha, S., Tong, H., Wongko, K., 2005. The Dinosaur fauna from the Khok Kruat Formation (Early Cretaceous) of Thailand. Proceedings of the International Conference on Geology, Khon Kaen (Thailand), Geotechnology and Mineral Resources of Indochina (GEOINDO), 575-581.

Buffetaut, E., Suteethorn, V., Tong, H., 2009. An early 'ostrich dinosaur' (Theropoda: Ornithomimosauria) from the Early Cretaceous Sao Khua Formation of NE Thailand. In: Buffetaut, E., Cuny, G., Le Loeuff, J., Suteethorn, V. (eds.). Late Palaeozoic and Mesozoic Ecosystems in SE Asia. London, Geological Society, 315 (Special Publications), 229-243.

Carrano, M.T., Sampson, S.D., Forster, C.A., 2002. The osteology of Masiakasaurus knopfleri, a small abelisauroid (Dinosauria: Theropoda) from the Late Cretaceous of Madagascar. Journal of Vertebrate Paleontology, 22, 510-534.

Charig, A.J., Milner, A.C., 1997. Baryonyx walkeri, a fish-eating dinosaur from the Wealden of Surrey. Bulletin of the Natural History Museum London, 53, 11-70.

Choiniere, J.N., Forster, C.A., De Klerk, W.J., 2012. New information on Nqwebasaurus thwazi, a coelurosaurian theropod from the Early Cretaceous Kirkwood Formation in South Africa. Journal of African Earth Sciences, 71-72, 1-17.

Cuenca-Bescós, G, Canudo, J.I., 2003. A new gobiconodontid mammal from the Early Cretaceous of Spain and its palaeogeographic implications. Acta Palaeontologica Polonica, 48, 575-582.

De Klerk, W.J., Forster, C.A., Sampson, S.D., Chinsamy, A., Ross, C.F., 2000. A new coelurosaurian dinosaur from the
Early Cretaceous of South Africa. Journal of Vertebrate Paleontology, 20, 324-332.

Delvene, G., Munt, M., Sender, L.M., 2011. Iberanaia iberica: The first record of the Trigonioidoidea Bivalvia: Unionoida from the Lower Cretaceous of Teruel, Spain. Cretaceous Research, 32, 591-596.

Galton, P.M., 1973. A femur of a small theropod dinosaur from the Lower Cretaceous of England. Journal of Paleontology, 47, 996-997.

Galton, P.M., Molnar, R.E., 2005. Tibiae of small theropod dinosaurs from Southern England: from the Middle Jurassic of Stonesfield near Oxford and the Lower Cretaceous of the Isle of Wight. In: Carpenter, K. (ed.). The carnivorous dinosaurs. Bloomington and Indianapolis, Indiana University Press, 3-22.

Gilmore, C.W., 1920. Osteology of the carnivorous Dinosauria in the United States National Museum, with special reference to the genera Antrodemus (Allosaurus) and Ceratosaurus. Bulletin of the American National Museum, 110, 1-154.

Gomez, B., Bamford, M., Martínez-Delclòs, X., 2002. Lower Cretaceous plant cuticles and amber (Kirkwood Formation, South Africa). Comptes Rendus Palevol, 1, 83-87.

Holtz, T.R., Molnar, R.E., Currie, P.J., 2004. Basal Tetanurae. In: Weishampel, D.B., Dodson, P., Osmólska, H. (eds.). The Dinosauria. Berkeley, University of California Press, 2nd edition, 71-110.

Huene, F. von, 1923. Carnivorous Saurischia in Europe since the Triassic. Bulletin of the Geological Society of America, 34, 449-458.

Ji, Q., Norell, M.A., Makovicky, P.J., Gao, K.-Q., Ji, S., Yuan, C., 2003. An early ostrich dinosaur and implications for ornithomimosaur phylogeny. American Museum Novitates, 3420, 1-19.

Jin, L., Chen, J., Godefroit, P., 2012. A new basal ornithomimosaur (Dinosauria: Theropoda) from the Early Cretaceous Yixian Formation, Northeast China. In: Godefroit, P. (ed.). Bernissart dinosaurs and Early Cretaceous terrestrial ecosystems. Bloomington, Indiana University Press Association, 466-487.

Kirkland, J.I., Britt, B.B., Whittle, C.H., Madsen, S.K., Burge, D.L., 1998. A small coelurosaurian theropod from the Yellow Cat Member of the Cedar Mountain Formation (Lower Cretaceous, Barremian) of eastern Utah. Bulletin of the New Mexico Museum of Natural History and Science, 14, 239248.

Kirkland, J.,Zanno, L., Deblieux, D., Smith, D., Sampson, S., 2004. A new, basal-most therizinosauroid (Theropoda: Maniraptora) from Utah demonstrates a Pan-Laurasian distribution for Early Cretaceous (Barremian) therizinosauroids. Journal of Vertebrate Paleontology, 24 (supplement to 3), 78A.

Kobayashi, Y., Lu, J.-C., Dong, Z.-M., Barsbold, R., Azuma, Y., Tomida, Y., 1999. Herbivorous diet in an ornithomimid dinosaur. Nature, 402, 480-481.

Lauprasert, K., Cuny, G., Buffetaut, E., Thirakhupt, K., Suteethorn, V., 2007. Siamosuchus phuphokensis, a new goniopholidid from the Early Cretaceous (ante-Aptian) of 
northeastern Thailand. Bulletin de la Société Géologique de France, 178, 201-216.

Lauprasert, K., Laojumpon, C., Saenphala, W., Cuny, G., Thirakhupt, K., Suteethorn, V., 2011. Atoposaurid crocodyliforms from the Khorat Group of Thailand: first record of Theriosuchus from Southeast Asia. Paläontologische Zeitschrift, 85, 37-47.

Le Loeuff, J., 1997. Biogeography. In: Currie, P.J., Padian, K. (eds.). Encyclopedia of Dinosaurs, Academic Press, 51-56.

Le Loeuff, J, Läng, E., Cavin, L., Buffetaut, E., 2012. Between Tendaguru and Bahariya: on the age of the Early Cretaceous Dinoaurs sites from the Continental Intercalaire and other African formations. Journal of Stratigraphy, 36, 486-502.

Long, J.A., Molnar, R.E., 1998. A new Jurassic theropod dinosaur from Western Australia. Records of the Western Australian Museum, 19, 121-129.

Lydekker, R., 1888. Catalogue of the fossil Reptilia and Amphibia in the British Museum. London, British Museum Natural History, 309pp.

Lydekker, R., 1889. Note on some points in the nomenclature of fossil reptiles and amphibians, with preliminary notices of two new species. Geological Magazine (Decade 3), 6, 325326.

Lydekker, R., 1891. On certain ornithosaurian and dinosaurian remains. Quarterly Journal of the Geological Society of London, 47, 41-44.

Makovicky, P.J., Apesteguía, S., Agnolin, F.L., 2005. The earliest dromaeosaurid theropod from South America. Nature, 437, 1007-1011.

Makovicky, P.J., Li, D., Gao, K.-Q., Lewin, M., Erickson, G.M., Norell, M.A., 2010. A giant ornithomimosaur from the Early Cretaceous of China. Proceedings of the Royal Society B, 277, 191-198.

Mateus, O., Dyke, G.J., Motchurova-Dekova, N., Kamenov, G.D., Ivanov, P., 2010. The first record of a dinosaur from Bulgaria. Lethaia, 43, 88-94.

Naish, D., 2000. A small, unusual theropod (Dinosauria) femur from the Wealden Group (Lower Cretaceous) of the Isle of Wight, England. Monatshefte, Neues Jahrbuch für Geologie und Paläontologie, 2000, 217-234.

Naish, D., 2011. Theropod dinosaurs. In: Batten, D.J. (ed.). English Wealden Fossils. London, The Palaeontological Association, 526-559.

Naish, D., Martill, D.M., 2002. A reappraisal of Thecocoelurus daviesi (Dinosauria: Theropoda) from the Early Cretaceous of the Isle of Wight. Proceedings of the Geologists' Association, 113, 23-30.

Naish, D., Martill, D.M., 2007. Dinosaurs of Great Britain and the role of the Geological Society of London in their discovery: basal Dinosauria and Saurischia. Journal of the Geological Society, 164, 493-510.

Naish, D., Hutt, S., Martill, D.M., 2001. Saurischian dinosaurs 2: theropods. In: Martill, D.M., Naish, D. (eds.). Dinosaurs of the Isle of Wight. London, The Palaeontological Association, 242-309.
Néraudeau, D., Allain, R., Ballèvre, M., Batten, D.J., Buffetaut, E., Colin, J.-P., Dabard, M.-P., Daviero-Gomez, V., El Albani, A., Gomez, B., Grosheny, D., Le Lœuff, J., Leprince, A., MartínClosas, C., Masure, E., Mazin, J.-M., Philippe, M., Pouech, J., Tong, H., Tournepiche, J.-F., Vullo, R., 2012. The HauterivianBarremian lignitic bone bed of Angeac (Charente, SW France): stratigraphical, palaeobiological and palaeogeographical implications. Cretaceous Research, 37, 1-14.

Norman, D.B., 1990. Problematic Theropoda: "Coelurosaurs". In: Weishampel, D.B., Dodson, P., Osmolska, H. (eds.). The Dinosauria. Berkeley, University of California Press, 280-305.

O'Connor, P.M., 2007. The postcranial axial skeleton of Majungasaurus crenatissimus (Theropoda: Abelisauridae) from the Late Cretaceous of Madagascar. In: Sampson, S.D., Krause, D.W. (eds.). Majungasaurus crenatissimus (Theropoda: Abelisauridae) from the Late Cretaceous of Madagascar. Society of Vertebrate Paleontology, 8 (Memoir), 127-162.

Olshevsky, G., 1991. A Revision of the Parainfraclass Archosauria Cope, 1869, Excluding the Advanced Crocodylia. San Diego (California), Publications Requiring Research, 196pp.

Owen, R., 1858. Monograph on the fossil Reptilia of the Wealden and Purbeck Formations. Part IV. Dinosauria (Hylaeosaurus). Palaeontological Society Monographs, 10, 1-26.

Pérez-Moreno, B.P., Sanz, J.L., Buscalioni, A.D., Moratalla, J.J., Ortega, F.J., Rasskin-Gutman, D., 1994. A unique multitoothed ornithomimosaur dinosaur from the Lower Cretaceous of Spain. Nature, 370, 363-367.

Rauhut, O.W.M., 2003. The interrelationships and evolution of basal theropod dinosaurs. Special Papers in Palaeontology, $69,1-215$.

Russell, D.A., 1993. The role of Central Asia in dinosaurian biogeography. Canadian Journal of Earth Sciences, 30, 2002-2012.

Seeley, H.G., 1888. On Thecospondylus daviesi (Seeley), with some remarks on the classification of the Dinosauria. Quarterly Journal of the Geological Society of London, 44, 79-86.

Senter, P., 2007. A new look at the phylogeny of Coelurosauria (Dinosauria: Theropoda). Journal of Systematic Palaeontology, 5, 429-463.

Sha, J., 2010. Historical distribution patterns of trigonioidids (non-marine Cretaceous bivalves) in Asia and their palaeogeographic significance. Proceedings of the Royal Society B, 277, 277-283.

Sues, H.D., 1997. On Chirostenotes, a Late Cretaceous oviraptorosaur (Dinosauria, Theropoda) from the western North America. Journal of Vertebrate Paleontology, 17, 698-716.

Welles, S.P., Long, R.A., 1974. The tarsus of theropod dinosaurs. Annals of the South African Museum, 64, 191-218.

Zanno, L.E., Makovicky, P.J., 2010. Herbivorous ecomorphology and specialization patterns in theropod dinosaur evolution. Proceedings of the National Academy of Sciences, 108, 232-237.

Manuscript received May 2013;

revision accepted May 2014;

published Online May 2014. 
